\title{
Hubungan Interpersonal Sebagai Pengukuhan Jaringan Sosial Dalam Kalangan Komuniti Bajau Laut Di Semporna, Sabah.
}

\author{
Aishah Hossin \\ Fakulti Kajian Pembangunan Dan Kepelbagaian Budaya \\ Kolej Universiti Yayasan Sabah
}

\begin{abstract}
Abstrak
Pengukuhan jaringan sosial dalam komuniti membantu ahlinya untuk saling memberikan sokongan bukan sahaja dalam bentuk fizikal tetapi juga emosi. Jaringan sosial biasanya dikaitkan dengan ikatan kekeluargaan yang dilihat sebagai satu bentuk hubungan yang dapat membantu dalam aliran pengetahuan dan sumber kepada ahli komuniti khususnya kepada mereka yang bermigrasi. Komuniti Bajau Laut di Semporna juga dikenali sebagai masyarakat sea nomad yang menjalankan aktiviti menangkap hasil laut dan menjalankan hampir sepenuhnya masa mereka di lepa. Dalam meneruskan kelangsungan hidup dan berdepan dengan arus modenisasi, komunti Bajau Laut telah berusaha memperbaiki hubungan interpersonal mereka untuk dijadikan asas kepada pengukuhan jaringan sosial dengan masyarakat disekeliling. Ini termasuklah hubungan interpersonal antara komuniti Bajau Laut sendiri dan komuniti tempatan. Objektif kajian ini adalah untuk mengkaji hubungan interpersonal yang diaplikasikan oleh komuniti Bajau Laut di dalam mengukuhkan lagi jaringan sosial mereka. Kajian ini melibatkan seramai sepuluh orang informan yang mana di peroleh melalui kaedah temu bual secara mendalam bersama key informan dan pemerhatian di lapangan. Dapatan kajian dianalisis menggunakan analisis tematik dan mendapati bahawa pengukuhan terhadap hubungan interpersonal yang tidak hanya terhad kepada komuniti Bajau Laut tetapi juga komuniti tempatan memberi ruang dan peluang kepada komuniti Bajau Laut untuk bergaul dan mendapatkan bantuan daripada bukan sahaja komuniti itu sendiri tetapi juga masyarakat tempatan.
\end{abstract}

Kata Kunci: Komuniti Bajau Laut, Hubungan Interpersonal dan Jaringan Sosial

\section{Pengenalan}

Semporna merupakan salah satu daerah yang terdapat di Sabah dan memiliki keunikan bukan sahaja dari aspek geografinya tetapi juga kepelbagaian etnik dan budayanya. Selain itu, daerah Semporna juga turut memiliki keunikan dari segi kewarganegaraan penduduknya yang mana di sekitar perairan Semporna wujud satu komuniti maritime yang dikenali sebagai Bajau Laut atau Pala'u. Etnik Bajau Laut tergolong di dalam rumpun keluarga Bahasa Bajau dan bermigrasi dari kepulauan Sulu (selatan Filipina) dan pantai timur Sulawesi (Yap Beng Liang, 1993). Dari perspektif kerajaan, mereka ini lebih dikenali sebagai stateless atau orang tanpa negara kerana tidak memiliki kad pengenalan diri daripada mana-mana negara baik Malaysia atau Filipina. Di Semporna komuniti Bajau Laut lebih sinonim untuk tinggal dan menetap di atas perahu yang juga di kenali sebagai lepa.

Lepa digunakan bukan sahaja untuk tujuan tidur dan beristirehat tetapi juga untuk aktiviti harian seperti masak dan membasuh kain. Lepa dianggap sebagai satu tempat atau ruang untuk komuniti Bajau Laut menghabiskan masa sepanjang hidup mereka di sana. Keadaan hanya berubah sekiranya mereka berkahwin, memiliki pertempatan di darat dan melakukan aktiviti masa senggang di pelantar atau darat. Kehidupan mereka yang lebih banyak tertumpu di dalam lepa dan berkisar kepada keadaan di laut yang sentiasa bergerak dan tidak statik menyebabkan hubungan mereka dengan ahli komuniti mereka juga menjadi lebih renggang. Ini ditambah lagi dengan sifat komuniti Bajau Laut yang pemalu dan tidak 
tahu berbahasa Melayu. Kengkangan dari segi bahasa dan kurang berinteraksi dengan masyarakat luar menyebabkan komuniti Bajau Laut sukar untuk memulakan interaksi dan lebih selesa berinteraksi dengan ahli komuniti mereka sendiri atau menghabiskan masa di lepa.

Penempatan komuniti Bajau Laut yang tidak statik iaitu di atas air, membolehkan mereka bergerak dengan mudah dari satu kawasan ke kawasan yang lain dengan menggunakan lepa dan menjadikan sumber laut sebagai salah satu mata pencarian mereka. Ini dibantu dengan adanya pengetahuan tempatan berkenaan dengan keadaan cuaca, aliran air laut dan keadaan muka bumi di sekitar kawasan penempatan mereka. Walaupun komuniti Bajau Laut sudah cukup selesa dengan keadaan hidup dan persekitaran mereka, tetapi mereka tidak dapat menolak untuk berdepan dengan modenisasi dan terpaksa akur untuk berinteraksi dengan komuniti tempatan dan di sekitar mereka.

Selain itu, mobiliti sosial yang berlaku dalam komuniti Bajau laut juga antara faktor yang mendorong mereka untuk lebih peka dan bersifat terbuka dengan perubahan yang berlaku disekeliling untuk menambahbaik lagi jaringan sosial yang ada. Yessi Marga dan Ekawati (2013) menyatakan bahawa jaringan sosial membantu dalam menstabilkan serta mewujudkan kondisi yang lebih selamat kepada individu untuk memulakan kehidupan di kawasan yang baru. Bagi komuniti Bajau Laut, jaringan sosial yang mereka perlukan adalah dari aspek hubungan timbal balik contohnya dari segi keperluan asas seperti makanan dan air bersih. Justeru, kertas kerja ini menyingkap hubungan interpersonal di kalangan komuniti Bajau Laut dalam mengukuhkan lagi jaringan sosial dalam komuniti mereka sendiri dan etnik lain yang berada di sekitar mereka.

\section{Latar Belakang dan Objektif Kajian}

Kawasan kajian yang dipilih adalah di sekitar kawasan perairan daerah Semporna yang berhampiran dengan Pulau Bumbum, Pulau Selakan dan Pulau Sebangkat (lihat Peta 1.1). Akses yang boleh digunakan untuk sampai ke kawasan-kawasan ini adalah melalui jalan laut dan merupakan kawasan yang menjadi tumpuan komuniti Bajau Laut untuk melabuhkan lepa mereka. Selain itu, terdapat juga kanak-kanak, wanita atau orang dewasa yang menggunakan perahu lebih kecil atau dikenali sebagai boggo untuk mengarang (mencari hasil laut) landak laut, ikan dan siput contohnya jenis dolen-dolen di sekitar kawasan tersebut. Dapatan hasil laut daripada aktiviti mengarang sebahagiannya akan disimpan untuk makanan sendiri dan sebahagian lagi di jual kepada komunti tempatan di sekitarnya dengan harga yang lebih murah berbanding dengan di pasar besar. Aktiviti mengarang ini dilihat sebagai salah satu punca ekonomi dan modal untuk komuniti Bajau Laut memulakan hubungan interpersonal mereka. 


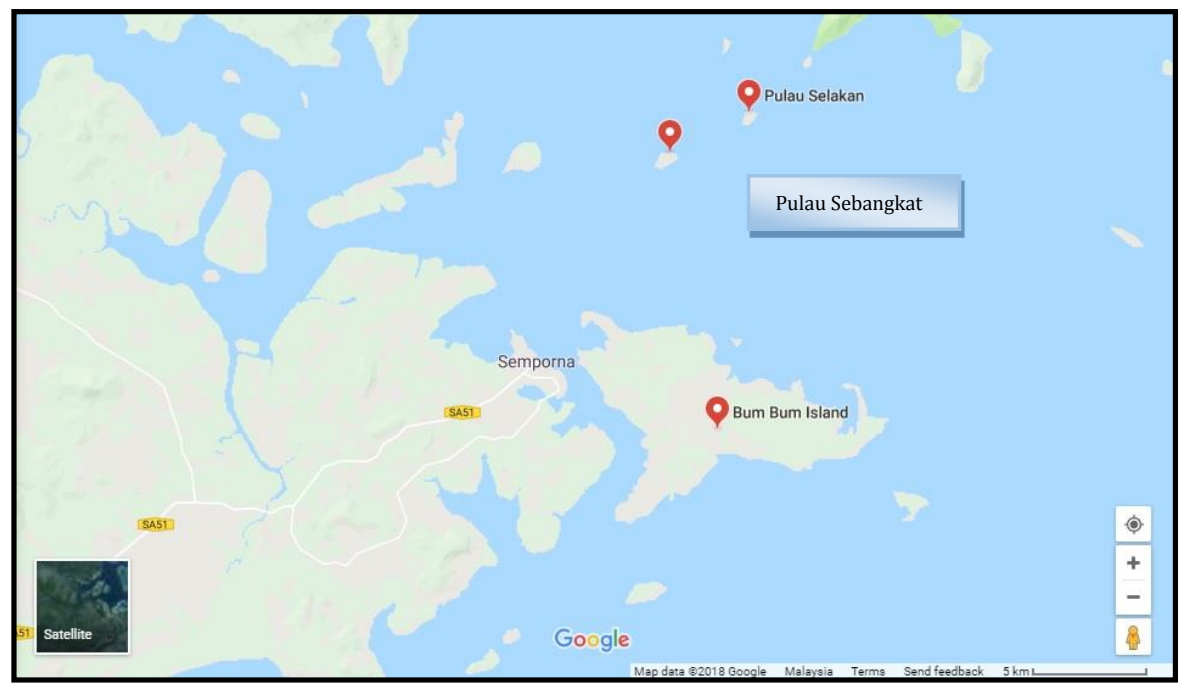

Peta 1.1: Kawasan Kajian di sekitar kawasan Pulau Bumbum, Pulau Selakan dan Pulau Sebangkat. Sumber: Google Maps (2018)

Kajian ini membincangkan hubungan interpersonal yang diaplikasikan oleh komuniti Bajau Laut dalam mengukuhkan lagi jaringan sosial agar dapat beradaptasi dengan perubahan yang berlaku di sekeliling mereka. Setiap perubahan atau pembangunan yang berlaku menuntut mereka lebih bersedia dan berusaha untuk berinteraksi bukan sahaja dalam kelompok komuniti mereka sendiri tetapi juga masyarakat luar yang menggunakan atau melalui kawasan penempatan mereka. Justeru, pihak berkuasa Negeri Sabah seperti immigresen, maritim dan pihak polis serta komuniti tempatan yang tinggal berhampiran telah berusaha mengekalkan keharmonian yang ada dengan membiarkan komuniti Bajau Laut dibiarkan hidup dengan bebas dan terasing di lepa.

\section{Metodologi Kajian}

Kajian ini melibatkan seramai sepuluh orang informan yang mana data di peroleh melalui kaedah temu bual secara mendalam menggunakan kaedah persampelan bertujuan dan pemerhatian di lapangan. Key informan yang dipilih adalah dari kalangan komuniti Bajau Laut tidak kira samada mereka tinggal di atas lepa atau sudah memiliki rumah di atas air. Key informan adalah mereka yang berumur diantara 27 hingga 63 tahun. Pemilihan key informan ini adalah berdasarkan kepada kebolehan mereka untuk menjelaskan khususnya berkenaan dengan transformasi sosial yang berlaku di dalam kehidupan mereka. Tambahan lagi, mereka merupakan individu yang sudah lama tinggal di atas lepa iaitu sejak daripada lahir (sekitar tahun lima puluhan sehingga sekarang) dan turut memiliki rumah di atas air (Pulau Sebangkat dan Pulau Selakan).

Dapatan kajian diperoleh daripada kaedah temu bual secara bersemuka dengan key informan. Dalam temu bual ini, key informan akan diajukan dengan pelbagai bentuk soalan seperti latar belakang dan bagaimana mereka menggunakan hubungan interpersonal dalam menguatkan jaringan sosial dengan komuniti tempatan. Selain itu, key informan turut ditanya berkenaan dengan hubungan mereka dan cara mereka mengekalkan hubungan baik dengan komuniti tempatan. Temu bual telah dilakukan di atas lepa, pelantar rumpai laut, jeti dan kawasan rumah komuniti tempatan. Durasi temu bual adalah lebih kurang sekitar 35 hingga 55 minit dan bahasa yang digunakan adalah Bajau Laut dan Bahasa Bahasa Melayu dengan menggunakan alat perakam suara atas persetujuan daripada key informan. Data yang diperolehi telah dianalisis menggunakan analisis tematik dan menjawab objektif kajian. 
Bagi menyokong dapatan kajian, sumber sekunder turut digunapakai dalam kajian ini bagi mendapatkan maklumat tentang kajian-kajian lepas yang berkaitan dengan tajuk kajian melalui kajian perpustakaan di perpustakaan induk Universiti Malaysia Sabah (UMS), Perpustakaan Negeri Sabah serta Dewan Bahasa dan Pustaka (DBP). Selain itu, maklumat yang diperolehi daripada laporan, laman web dan artikel yang dikeluarkan oleh kerajaan berkenaan dengan fokus kajian turut digunakan bagi menambah data yang diperlukan.

\section{Dapatan kajian dan Perbincangan}

Terdapat dua dapatan kajian yang telah diperoleh daripada analisis tematik yang dilakukan iaitu (i) hubungan interpersonal komuniti Bajau laut dan (ii) Pengukuhan jaringan sosial sebagai satu bentuk pengekalan tradisi dan hidup.

\section{i. Hubungan Interpersonal Komuniti Bajau Laut}

Hubungan interpersonal boleh didefinisikan sebagai satu bentuk komunikasi yang dilakukan dengan berinteraksi dan memahami orang lain (Gardner, 1993; Diki, 2017). Dalam melakukan interaksi, komunikasi yang berkesan dapat melahirkan satu suasana timbal balik yang lebih harmoni dan boleh mengukuhkan lagi hubungan serta jaringan sosial. Selain itu, kemahiran interpersonal juga dilihat sebagai salah satu aspek yang penting dalam menyampaikan maklumat dan mendapatan maklumat. Komunikasi interpersonal juga merupakan komunikasi yang di lakukan secara bersemuka dan saling pengaruh mempengaruhi persepsi lawan bicaranya (Sapril, 2011)

Selain itu, hubungan interpersonal khususnya di antara kampung, ahli komuniti dan masyarakat sekitar boleh dianggap sebagai satu strategi kepada golongan migran untuk lebih mudah menyesuaikan diri dengan situasi di persekitaran mereka (Gusni, 2010). Ini kerana, melalui hubungan interpersonal, golongan migran akan berupaya untuk beradaptasi dan mendapatkan bantuan asas seperti tempat tinggal dan makanan sebelum mereka dapat berdikari serta menyediakan keperluan sendiri. Kajian mendapati bahawa komuniti Bajau laut menggunakan komunikasi interpersonal dalam pelbagai situasi bukan sahaja dalam ruang lingkup lepa bersama komuniti Bajau Laut sendiri tetapi juga masyarakat di sekeliling mereka. Komunikasi interpersonal yang mereka aplikasikan ini membentuk satu hubungan interpersonal yang dapat membantu mereka dalam banyak perkara seperti pekerjaan, hubungan persanakan dan sokongan sosial.

Pada asalnya hubungan interpersonal komuniti Bajau Laut hanya tertumpu kepada hubungan yang bersifat kekeluargaan. Ini kerana kedudukan komuniti ini yang memang terasing dan lebih banyak menghabiskan masa mereka di lepa menyebabkan mereka lebih selesa untuk melakukan hubungan interpersonal di kalangan mereka sahaja. Tambahan lagi, perasaan takut dan malu untuk berkomunikasi dengan masyarakat luar turut menjadi penyumbang kepada keadaan tersebut. Situasi ini disebabkan oleh keadaan fizikal komuniti Bajau Laut itu sendiri yang biasa hidup terasing dan lebih banyak bergaul dengan ahli keluarga serta tidak pandai berbahasa Melayu.

Komuniti Bajau Laut pada kebiasaannya hanya pergi ke kawasan darat untuk tujuan melawat, mendapatkan barang keperluan, beristirehat di atas pelantar atau rumah kawan khususnya semasa cuaca panas dan angin kuat. Komuniti Bajau Laut juga akan turut sama memeriahkan majlis saudara mara dan rakan mereka apabila mereka diundang tetapi kebanyakkan masa mereka lebih suka dihabiskan di atas lepa seperti yang dinyatakan oleh key informan: 
“...ada juga kami berkawan sana di Selakan pun ada keluarga tapi malu juga kalau balik-balik ke sana kecuali kalau ada apa-apa macam kahwin ka kenduri baru pergi..." (KI 7, 33 tahun).

Hubungan interpersonal ini mula berkembang dengan adanya hubungan yang baik di antara komuniti tempatan dengan Bajau Laut. Hubungan yang baik ini terus dikekalkan melalui sistem pertukaran barang keperluan harian seperti tepung dan gula dengan hasil laut serta melalui pemindahan pengetahuan tentang sistem pengkulturan rumpai laut. Pertukaran barang berlaku melalui pertukaran tangkapan hasil laut seperti ikan dan sotong kepada barang keperluan asas. Ini dijelaskan oleh key informan:

“...selalu juga kalau dapat banyak hasil masa mengarang itu kami hantar sejak ke rumah dorang...kadang tidak bayar guna duit tapi apa yang kami perlu macam tepung ka atau gula ka bergantunglah..." (KI 1, 27 tahun).

Komuniti tempatan menggunakan kepakaran yang ada pada komuniti Bajau Laut untuk menjalankan perusahaan rumpai laut samada melalui sistem pekerja-majikan, rakan kongsi dan modal aset-tenaga. Perusahaan rumpai laut menggunakan sistem pekerja-majikan memerlukan komuniti Bajau Laut untuk menjadi pekerja dan mendapatkan upah samada secara harian atau bulanan tetapi jika mengikut sistem ini komuniti tempatan lebih selesa untuk memberikan upah secara bulanan kerana jika upah diberikan secara harian, komuniti Bajau Laut hanya akan bekerja semasa mereka memerlukan barang atau upah sahaja.

Bagi perusahaan rumpai laut menggunakan sistem rakan kongsi pula, kebiasaannya komuniti Bajau Laut yang dipilih merupakan individu yang dikenali secara rapat dan dipercayai oleh komuniti tempatan serta memiliki kediaman di atas air. Sistem rakan kongsi memerlukan komuniti Bajau Laut untuk lebih komited dan turut sama berusaha daripada pengeluaran modal iaitu dari segi rumpai laut sehinggalah kepada proses penjualan.

Manakala sistem modal aset-tenaga pula lebih menjurus kepada perusahaan rumpai laut yang bersifat situasi menang-menang (win-win situation). Dalam sistem modal asettenaga, pembahagian tugas dan peranan akan dilakukan yang mana pada peringkat aset seperti benih rumpai laut, tali, pelampung dan kawasan pengkulturan akan disediakan oleh komuniti tempatan termasuklah pada peringkat yang terakhir iaitu penjualan yang mana hasil jualan itu nanti akan dibahagi sama rata. Manakala, komuniti Bajau Laut pula lebih menjurus kepada penggunaan tenaga untuk melakukan proses pembibitan benih rumpai laut sehingga kepada proses penuaian dan pengeringan rumpai laut mengikut gred.

Kajian menunjukkan bahawa dengan berkembangnya industri pengkulturan rumpai laut di Semporna, komuniti Bajau laut menjadi semakin penting bukan sahaja disebabkan guna tenaga mereka sebagai pekerja tetapi juga sebagai rakan kongsi dan pemberi tunjuk ajar. Ini kerana, teknik pengkulturan rumpai laut yang diwarisi daripada generasi ke generasi oleh komuniti Bajau laut menjadikan mereka etnik yang memiliki kepakaran dalam mengusahakan pengkulturan rumpai laut. Keadaan ini secara tidak langsung membantu komuniti Bajau laut untuk tetap meneruskan tradisi mereka dari aspek penggunaan kepakaran ilmu kelautan dan pengekalan budaya dan tradisi tinggal di lepa.

Tidak hanya tertumpu kepada orang dewasa sahaja, anak-anak komuniti Bajau Laut juga diajar tentang ilmu kehidupan melalui pemindahan pengetahuan tempatan sejak dari 
mereka berusia empat hingga lima tahun lagi dengan membiarkan anak-anak ini menggunakan boggo untuk tujuan mengarang. Kanak-kanak inilah yang akhirnya membentuk satu lagi hubungan interpersonal yang baru kepada komuniti Bajau Laut. Anakanak komuniti Bajau laut bukan sahaja lebih berani untuk berdepan dengan etnik lain dan memulakan komunikasi interpersonal tetapi membuka ruang dan peluang kepada ibu bapa mereka untuk memperluaskan pergaulan. Ini diperkukuhkan dengan penyataan informan:

“...budak-budak yang lagi cepat berkawan daripada kami sudah mereka kenal jadi kalau kami lalu pun kawasan sana mereka akan tegur dan tanya kami dari sana kami kenal la..." (KI3, 45 tahun; KI 10, 63 tahun).

Pada peringkat ini, anak-anak komuniti Bajau Laut sudah mula membina asas perhubungan dengan komuniti tempatan walaupun pada awalnya hubungan yang terbentuk adalah hasil daripada interaksi untuk mendapatkan hasil laut dengan harga yang lebih murah. Namun, kepercayaan dan interaksi yang baik diantara komuniti Bajau Laut dan komuniti tempatan telah menjalinkan hubungan persahabatan diantara ibu bapa mereka. Ini secara tidak langsung membuka ruang kepada komuniti Bajau Laut untuk memperkukuhkan jaringan sosial mereka khususnya semasa mereka memerlukan bantuan seperti tempat berteduh semasa angin kuat dan sakit.

\section{ii. Pengukuhan Jaringan Sosial Sebagai Satu Bentuk Pengekalan Tradisi dan Kelangsungan Hidup}

Jaringan sosial merupakan satu bentuk ikatan perhubungan yang terhasil di antara sekelompok individu yang mana ianya boleh mempengaruhi perilaku sosial individu yang terlibat. Dari aspek migrasi, jaringan sosial terbentuk bukan sahaja antara ahli komuniti tetapi juga dengan masyarakat setempat (Yessi Marga dan Ekawati, 2013). Analisis tematik turut mendapati bahawa interaksi interpersonal dalam kalangan komuniti Bajau Laut sendiri dan komuniti tempatan merupakan satu bentuk usaha mereka untuk mengukuhkan jaringan sosial sebagai pengekalan tradisi dan hidup mereka.

Keadaan mereka yang sukar untuk mendapatkan akses kepada kemudahan seperti pendidikan dan kesihatan menuntut mereka untuk lebih berusaha keras secara konvensional contohnya dalam mencari daun-daun atau pokok yang boleh digunakan untuk tujuan perubatan dan kecantikan. Ini kerana, walaupun mereka inginkan perubahan dalam kehidupan mereka dari aspek kuasa beli yang kukuh dan mendapatkan pekerjaan yang bagus tetapi situasi yang membelenggu mereka tidak memungkinkan mereka mencapainya (Gusni, 2010).

Sejajar dengan itu, pengukuhan jaringan sosial adalah penting dan perlu di lakukan oleh komuniti Bajau laut bagi menjamin pengekalan tradisi dan hidup mereka. Perkahwinan di antara komuniti Bajau Laut dan komuniti tempatan juga turut mendorong kepada hubungan interpersonal yang lebih luas. Ini kerana melalui perkahwinan, pergaulan di antara komuniti Bajau Laut dan komuniti tempatan juga menjadi lebih erat. Ini dijelaskan dengan pandangan key informan:

“...ada keluarga kami juga yang tinggal di Bumbum kalau kami pergi sana senang juga sebab ada keluarga yang kahwin kan sana...kalau sudah kawin begitu sana sini pun keluarga sudah jadi kalau perlu bantuan atau apa kurang sudah segan..." (KI 4, 47 tahun). 
Walaupun perkahwinan bersifat endogami adalah lebih diutamakan dalam komuniti Bajau Laut berbanding perkahwinan bersifat eksogami kerana pengekalan tradisi dianggap penting sebagai kelangsungan budaya dalam komuniti Bajau Laut. Namun, perkahwinan di kalangan komuniti Bajau Laut dan komuniti tempatan tetap direstui oleh komuniti Bajau Laut. Perkahwinan eksogami juga membolehkan tradisi budaya dapat dikembang dan diperkaya dengan tradisi budaya etnik lain.

Tambahan lagi, melalui perkahwinan eksogami komuniti Bajau Laut akan mendapat akses yang lebih baik terhadap kemudahan seperti peluang pekerjaan, kemudahan asas, kesihatan dan petempatan di atas air. Pengukuhan jaringan sosial yang terbentuk dapat membantu komuniti Bajau laut untuk terus bergerak dengan bebas dan mendapatkan barangan keperluan mereka di darat dengan lebih mudah dan cepat. Ini disokong dengan penyataan informan:

“...kami ada juga ke darat kalau mau ambil barang ka atau ada perlu macam kami ni pigi hospital pun susah duit pun tiada ic pun tiada jadi kalau kami kacau mereka susah juga kami mahu pergi sana darat ambil apa-apa..." (KI 3, 45 tahun).

Selain itu, dapat dilihat hubungan interpersonal antara komuniti Bajau Laut dan komuniti tempatan secara tidak langsung merupakan komunikasi di antara budaya lain dalam mencapai matlamat komunikasi yang mana dalam konteks kajian ini adalah untuk menguatkan jaringan sosial di antara etnik dan pengekalan kepada tradisi budaya komuniti Bajau Laut.

\section{Kesimpulan}

Kesimpulannya, jaringan sosial tidak hanya tertumpu kepada hubungan kekeluargaan sahaja tetapi juga meliputi hubungan di antara komuniti dan juga masyarakat di sekelilingnya. Jaringan sosial boleh terbentuk dengan hanya berkongsi minat yang sama, cara kehidupan atau melalui keperluan mereka dalam saling melengkapi. Justeru, dalam mengukuhkan jaringan sosial yang ada, komuniti Bajau laut telah cuba untuk membuka ruang mereka kepada masyarakat luar untuk mendekati mereka dan seterusnya melakukan hubungan interpersonal dengan mereka. Melalui cara ini, jaringan sosial mereka bukan sahaja dapat diperkukuhkan malah dapat membantu mereka untuk terus mapan dan menjalani kehidupan mereka dengan lebih harmoni bersama dengan etnik lain.

\section{Rujukan}

Diki Alfandi. 2017. Komunikasi Interpersonal Keluarga Muslim dalam Mengantisipasi Penyalahgunaan Narkoba pada Remaja di Keluharan Sukabumi Bandar Lampung. Penulisan tesis Sarjana Sosial Jurusan Komunikasi dan Penyiaran Islam. Indonesia: Universiti Islam Negeri Raden Intan Lampung.

Gardner, H. 1993. Multiple Intelligences: The Theory in Practice. New York: Basic Book. Gusni Saat. 2010. Sama Bajau Dalam Kanca Urbanisasi: Pengalaman di Teluk Bone, Sulawesi Selatan. Kota Samarahan: Universiti Malaysia Sarawak.

Google Maps. 2018. Kawasan Kajian di sekitar kawasan Pulau Bumbum, Pulau Selakan dan Pulau Sebangkat dalam https://www.google.com/maps/search/selakan +bumbum+dan+sebangkat/@4.5000065,118.5355629,11.5z diakses pada 12 Disember 2018. 
Sapril. 2011. Komunikasi Interpersonal Pustakawan. Jurnal Iqra' Volume 05 No.01 Mei, 2011.

Yap Beng Liang. 1993. Orang Bajau Pulau Omadal: Satu Kajian tentang Sistem Budaya, Kuala Lumpur: Dewan Bahasa dan Pustaka.

Yessi Marga Safitri dan Ekawati Sri Wahyuni. 2013. Jaringan Sosial Dan Strategi Adaptasi Tenaga Kerja Migran Asal Lampung Di Desa Jayamukti, Kecamatan Cikarang Pusat, Kabupaten Bekasi, Provinsi Jawa Barat. Jurnal Sosiologi Pedesaan, ISSN: 2302 7517, Vol. 01, No. 01 April 2013, hlm: 64-77. 